female shags ( $<6$ per cent) with liver concentrations of about 9 p.p.m. of dieldrin. It is possible that this is the result of sub-lethal effects, but much of the egg breaking is caused by polygyny. Much more detailed and critical attention than hitherto should be given to experimental studies of the sub-lethal effects of insecticides.

I thank Shell Research Limited, particularly Dr J. Robinson and A. N. Crabtree, for doing the analyses, and the Farne Islands Committee of the National Trust for permission to work on the Farne Islands. I also thank Dr N. W. Moore and Dr D. Ratcliffe of the Nature Conservancy and Dr J. C. Coulson and Dr M. Stone, University of Durham, for their help.

Department of Zoology,

G. R. Poxts

University of Durham.

Received February 22, 1968.

${ }^{2}$ Ratcliffe, D. A., Bird Study, 10, 56 (1963).

'Ratcliffe, D. A., Nature, 215, 208 (1987).

Jefferies, D. J., and Prestt, I., Brit. Birds, 59, 49 (1966).

${ }^{4}$ Robinson, J., Chem. Indust.,1967, 1974 (1967).

Turtle, E. E., Taylor, A., Wright, E. N., Thearle, R. J. P., Egan, J., Evans, W. H., and Soutar, N. M., J. Sci. Fd. Agric., 14, 567 (1963).

- Lockie, J. D., and Ratcliffe, D. A., Brit. Bird8, 57, 89 (1964).

' Ratcliffe, D. A., Bird Study, 14, 238 (1967).

${ }^{8}$ Tubbs, C. R., Brit. Birds, 60, 381 (1967).

- Keith, J. A., J. Appl. Ecol., 3 (Suppl.), 71 (1966)

${ }_{10}$ Ames, P. L., J. Appl. Ecol., 3 (Suppl.), 87 (1968).

11 British Trust for Ornithology/Royal Society for the Protection of Birds, Committee on Toxic Chemicals Rep8, 4, 5 and 6 (1964, 1965 and 1967).

12 Robinson, J., Richardson, A., Crabtree, A. N., Coulson, J. C., and Potts G. R. Nature, 214, 1307 (1967).

(1958).

${ }^{14}$ Romanoff, A. L., and Romanoff, A. J., The Avian Egg (Wiley, New York, 1949).

${ }^{15}$ Korte, F., and Arent, H., Life Sciences, 4, 2017 (1965).

${ }^{16}$ Korte, F., Botyu-Kagaku, 32, 46 (1967).

${ }^{17}$ MeLaughlin, jun., J., Marliac, J. P., Verrett, M. J., Mutchler, M. K., and Fitzhugh, O. G., Toxicol. Appl. Pharmacol., 5, 760 (1963).

${ }^{18}$ Dunachie, J. F., and Fletcher, W. W., Nature, 212, 1062 (1966).

${ }^{10}$ Koeman, J. H., Oudejans, R. C. H. M., and Huisman, E. A., Nature, 215 1094 (1967).

${ }^{20}$ Ann. Rep. Patuxent Wildlife Research Center, Circ. Fish Wildl. Serv., Wash., 167, 199, $224(1963,1964$ and 1965).

"1 Robinson, J., Brown, V. K. H., Richardson, A., and Roberts, M., Life Sciences, 6, 1207 (1967)

${ }^{22}$ Robinson, J., Nature, 215,33 (1967).

${ }^{23}$ Potts, G. R., J. Anim. Ecol. (in the press).

st De Witt, J. B., Crabtree, D. G., Finley, R. B., and George, J. J., Cire, Fish Wildl. Serv., Wash., 143, 14 (1962).

${ }^{25}$ Rudd, R. L., Pesticides and the Living Landscape (Wisconsin, 1964).

${ }^{26}$ McEwen, L. C., and Brown, R. L., J. Wildl. Mgmt., 30, 604 (1966).

${ }^{27}$ Peakall, D. B., Nature, 216, 505 (1967).

${ }^{28}$ Dési, I., Farkas, I., and Kemény, T., Experientia, 24, 51 (1968).

${ }^{29}$ Ratcliffe, D. A., Brit. Birds, 58, 128 (1960).

${ }^{30}$ Lockie, J. D., and Ratcliffe, D. A., Brit. Bird8, 57, 89 (1964).

${ }^{31}$ Treleaven, R. B., Brit. Birds, 54,136 (1961).

32 Jourdain, F. C. R., Brit. Birds, 7, 94 (1913).

s Robertson, D. J., Brit. Birds, 33, 55 (1939).

st Williamson, K., Brit. Birds, 33, 116 (1939).

${ }^{35}$ Marples, G., and Marples, A., Sea Terns (Country Life, London, 1934).

"Armstrong, E. A., Bird Display and Behaviour (Lindsay Drummond, London, 1947).

\section{Discovery of Rhabdopleura (Hemichordata) at Plymouth}

Rhabdopleura is one of three pterobranch genera which as hemichordates are important in our understanding of the evolution of the chordates ${ }^{2}$. Its biology and life cycle are very incompletely understood. So far, the most suitable marine laboratory for studying this genus has been Bergen, where $R$. normani has been well investigated $^{2}$. This species, however, has to be kept at temperatures less than $12^{\circ} \mathrm{C}$, and is dredged from a hard, rocky bottom in rather deep water.

The habitat of $R$. normani, the best known species, extends from within the Arctic Circle southward to the Azores, but, apart from a few records in shallow waters of some Norwegian fjords ${ }^{2}$, it inhabits deep water, usually on the continental slope. In April 1967, specimens of Rhabdopleura were dredged for the first time from 1 to 2 miles south of Stoke Point in Devon. They have been identified as $R$. compacta Hincks ${ }^{3}$, having the highly characteristic colonial form described by him. R. com. pacta, which was described inadequately from poorly preserved material, is not at present regarded as a valid species, but when a description of the new material has been prepared it is intended to re-instate it. $R$. compacta was first found off the coast of Northern Ireland in 1880. Since then it has been recorded once only, off Finistère. All the colonies from Stoke Point were found adhering to the concave sides of dead lamellibranch shells (mainly Glycimeris glycimeris) at a depth of 75-80 ft. They occurred on more than 60 per cent of the shells in one dredge haul and have also been obtained by diving.

The life cycle of Rhabdopleura is poorly understood. Recent authors agree with Schepotieff ${ }^{4}$ that Rhabdopleura is dioecious. Observations on the material from Stoke Point have already revealed some points of importance. A number of female, but no male zooids have been found. They can be recognized by the presence of large ovoid eggs in the metacoel. It appears that these eggs may be released proximally, through a temporary opening at the posterior end of the metasome, to develop in the tube of the parent in much the same way as in Cephalodiscus. If this is so, the gonoduct seems to have no function except as a possible point of entry for spermatozoa. Fertilization in Rhabdopleura may therefore prove to be internal. After liberation into the tube the embryos develop and acquire a coating of cilia. They then probably crawl from the tube by squeezing past the zooid to begin their free life, presumably as larvae ${ }^{5}$, although this stage has never been described.

Previous authors ${ }^{4,6}$ have noted the rarity of sexual zooids and the disproportionate ratios of each sex. Vaney and Conte $^{6}$ believed $R$. normani to be a protogynous hermaphrodite, because they found a male with what they thought to be an ovary at the base of its stalk, but subsequently ${ }^{4}$ this interpretation was considered to be erroneous, leaving their observations unexplained. Structures similar to those figured by them as an ovary (Pl. 8, Figs. 32, 36 and 42) have been found in $R$. compacta. It appears that the base of the contractile stalk may bud off gemmae which develop in the tube of the parent in the same way as the sexually produced embryos. A figure which Lankester ${ }^{7}$ could not interpret (his Pl. 39, Fig. 2) provides corroborative evidence for this hypothesis. It shows part of the creeping tube of a zooid in which there are six embryos. One is attached to the contractile stalk, and appears to be budding from it. The colonies of Rhabdopleura may thus multiply asexually, as well as enlarging in this way.

It is hoped to develop these studies on Rhabdopleura. I wish to thank Drs E. and A. Southward and the Director of the Marine Biological Association's Laboratory for assistance, and also Professor E. W. Knight-Jones and Dr J. S. Ryland for helpful discussions. This work was supported by a Natural Environment Research Council research studentship.

\section{A. R. D. Stebbing}

Department of Zoology,

University College of Swansea.

Received February 8; revised February 23, 1968.

1 Berrill, N. J., The Origin of Vertebrates (Oxford, 1955).

2 Burdon-Jones, C., Univ. Bergen Arb. Naturv. R., 11, 1 (1954).

3 Hincks, T., History of British Marine Polyzoa (London, 1880).

${ }^{4}$ Schepotieff, A., Zool. Jb. (Anat.), 23, 463 (1907).

5 Burdon-Jones, C., in Parker and Haswell's Textbook of Zoology, 2, Seventh edit. (revised by Marshall, A. J.) (London, 1964).

6 Vaney, A., and Conte, A., Rev. Suisse Zool., 14, 143 (1906).

'Lankester, E. R., Q. J. Microsc. Sci., 24, 622 (1884). 